\title{
キレート分析法による重質石油 製品中の全イオウ分の定量*
}

\author{
古 賀 雄 造** 梶川正 雄** 野 中 欣一**
}

Determination of Total Sulfur in Heavy Petroleum

Products by Chelatometry*

by Yūzō Koga**, Masao Kajikawa** and Kin-ichi Nonaka**

\begin{abstract}
Total sulfur content in heavy petroleum products has been determined by the test methods according to JIS K-2263 or ASTM D-129 as follows.

An oil sample is perfectly burned in the bomb, and the generated sulfur oxides are absorbed in $\mathrm{Na}_{2} \mathrm{CO}_{3}$ solution, and then oxidized by $\mathrm{Br}_{2}$ solution.

Thus, they are converted to sulfates, and total sulfur content is determined as $\mathrm{BaSO}_{4}$ by gravimetric procedure.

These methods are accurate, but a long time is required for the determination; so they are not suitable for controlling process and are replaced by a more rapid method at present.

Under the above circumstances, the authors investigated on this problem, and established a rapid method almost as precise as the bomb method.

That is; oil sample is burned in the bomb, and a slight excess of Ba-EDTA is added to the sulfuric acid solution produced, and then, the isolated EDTA is back-tirated with standard $\mathrm{BaCl}_{2}$ solution using $\mathrm{PC}$-indicator.
\end{abstract}

\section{1. 緒言}

重質石油留分中の全 1 オウ分は，JIS K-2263"1) または ASTM D-1292) の武験法従って式料をボンブで然烧し，発 生するイオウ酸化物を炭酸ナトリウム溶液に吸収酸化させ, 生 成する硫酸ナトリウムを湓化パリウムによって硫酸バリウムと し, 就成後口別水洗して重量法により定量している。との方法 は種々の試験法中精度がすぐれていろので，石祄中のイオウ分 試験の標隼法になっている。とてろか同法は試㙠に長㭙間を要 し，日常の管理試釦としては不向きである。てれらに対し滴定 法は試験時間短かく融通性のある方法である。との試験法に属 するもので従来より広く実施されている方法には，石英管燃烧 法3、れがあるが，塩素またはりンを含む試料については，てれ らの干涉のため精度よく测定できない久点がある。

電導度滴定法" は邀当のようであるが，電導度测定用の高価 な機器を要し一般的でない。

その他クロム酸パリウムあるいはモリブデン酸バリウムによ

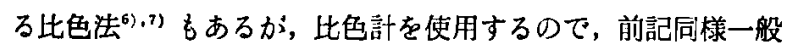
的でない。

これらに対し硫酸イオンを含む溶液を EDTAで滴定するキ

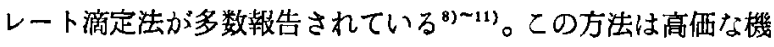
器を使用せず操作が簡単で迅速正確に分析值が得られる点で, 他の方法よりすぐれていると思われる。その一例としてアトマ イザーバーナー法8) か蕔告されているが，これは装置操作が やや複雑の感がする。そてで著者らは、ボンブ法により生成さ

* 炤和 35 年 5 月 7 日受理

** 傎覀燃料工業株式会社研究所 Tōa Nenryō Kōgyō K.K. Research Lab.
れる硫酸イオンの定量に EDTA を用いて滴定するいわゆるキ レート分析法の適用について調查した。キレート分析法の金属 指示楽としては, エリオクロムブラック丁を使用した報文も 多いが、水洨液およびアルコール溶波のいずれにおいても案外 不安定であり, 終点の変色が不鮮明になるので, 割合安定で使 用しやすいフタレインコンプレキンン指示液を用い，直接滴定 之逆滴定の雨法の精度, 重質石油留分中に混入すると推察され ろ共存イオンによる影響, ボンブ然橴操作上の諸条件, 测定操 作上の諸条件を榆討し，最適方法を確立した。

\section{2. 装置 \\ 1) ボンブ}

JIS K-2263 規定の容量約 $300 \mathrm{~m} l$, ステンレス製ボンブにし て，付属パッキンはネオプレン製のもの。

2) 試料ザラ

底部内径約 $24 \mathrm{~mm}$, 上部内径約 $27 \mathrm{~mm}$, 高さ約 $12 \mathrm{~mm}$ の白 金斐のもの。

3) 点火線

画径約 $0.4 \mathrm{~mm}$ の白金緗 および定量用無灰口紙（東洋口紙 No. 5 C)。

\section{3. 試料および試薬 $ノ$}

1) イオウ分合成試料

ジヘンシルジルフフイド $\left(\mathrm{C}_{6} \mathrm{H}_{5} \mathrm{CH}_{2}\right)_{2} \mathrm{~S}_{2}$ をホワイトオイル 亿溶解しイオウ分含有量 $1.02 \mathrm{wt} \%$ のイオウ分既知の合成試料 を調製した。ただしジベンジルジルファイドの純度不明のた め, JIS K-2263 法によろ多数回のくり返し試験值をもって哓 知量とした。その他最低 $0.01 \mathrm{wt} \%$ 程度のイオウ分含有㻎まで 
の種々の台成試料を調製した。

2) 石油留分試料

原油，軽许，潤滑油留分 計 11 程を武料とした。

3） $0.01 \mathrm{M}$ 塩化バリウム標準溶液

武莧特級塩化バリウム $\left(\mathrm{BaCl}_{2} \cdot 2 \mathrm{H}_{2} \mathrm{O}\right)$ を再絬晶して精裂し， その $2.4431 \mathrm{~g}$ をはかり取り，純水に溶解して $1 l$ とする。重 量法によりその力価を求める。

4) $0.01 \mathrm{M}$ および $0.02 \mathrm{M}$ Ba-EDTA 溶液

武䒚特級 Ba-EDTA 錯㙁 $\left(\mathrm{C}_{10} \mathrm{H}_{12} \mathrm{~N}_{2} \mathrm{O}_{8} \mathrm{Na}_{2} \mathrm{Ba} \cdot 5 \mathrm{H}_{2} \mathrm{O}\right) \quad 5.5$ $\mathrm{g}$ および $11.0 \mathrm{~g}$ を純水に溶解して $1 l$ とする。

5) フタレインコンプレキソン (PC) 指示液

PC $0.2 \mathrm{~g}$ およびナフトールグリーン $0.02 \mathrm{~g}$ をメタノール $100 \mathrm{ml}$ に溶解する。

6)濃塩酸（比重 1.18）および塩酸 $(1: 4)$

7) 酸化剂

飽和臭素水わよび過酸化水素水 (30\%)

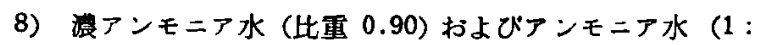
1)

9) エタノール(95\%)

10）炭酸ナトリウム溶液

試薬特級無水炭酸ナトリウム $50 \mathrm{~g}$ を純水に溶解して $1 l$ と する。

\section{4. 実験}

\section{1 滴定点における残色度}

塩化バリウム標準容花にアンモニア水を加えて $\mathrm{pH} 11$ とし， フタレインコンプレキソン指示液 $0.2 \mathrm{~m} l$ を加えて，コタキ光 電此色計により $2 \mathrm{~cm}$ セルで Ba-PC の级光帯を謂查した。絬 果は第1図のどとく最大吸収波長は $580 \mathrm{~m} \mu$ のととろにあり， この溶液を EDTA 標準溶花で滴定すると、Ba-EDTA を生成 し，溶液中の Ba-PC の诚少とともに紫赤色が薄くなるが，終 点においても無色にならない。乙れは $\mathrm{pH}$ の上昇とともに $\mathrm{PC}$ の解離が進み，深紅色の色素イオンが当量点を越えても残るた めと考えられる。しかしこの色素自身の呈色はアルコール溶液 中では非常に弱くなろので，アルコールおよび PC 指示液添 加量について梌討した。

$50 \mathrm{ml}$ 中 $13.4 \mathrm{mg}$ のバリウムイオン濃度の塩化バリウム谷

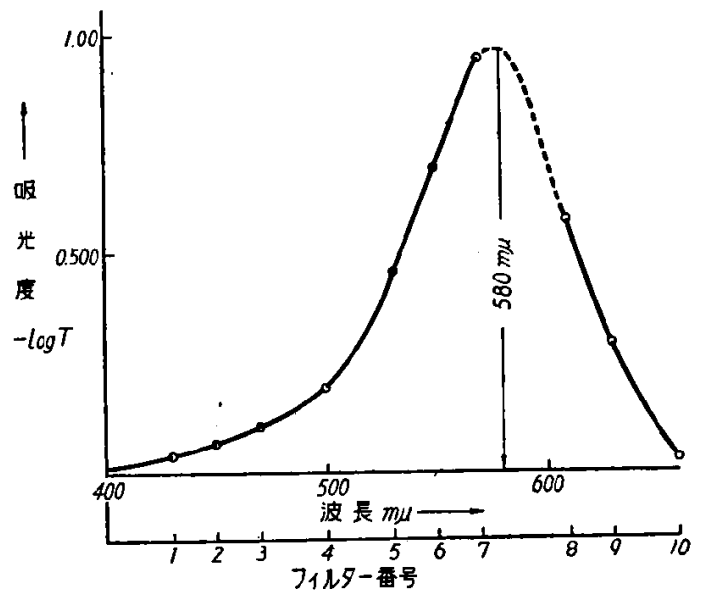

第1圈 Ba-PC の吸収曲線

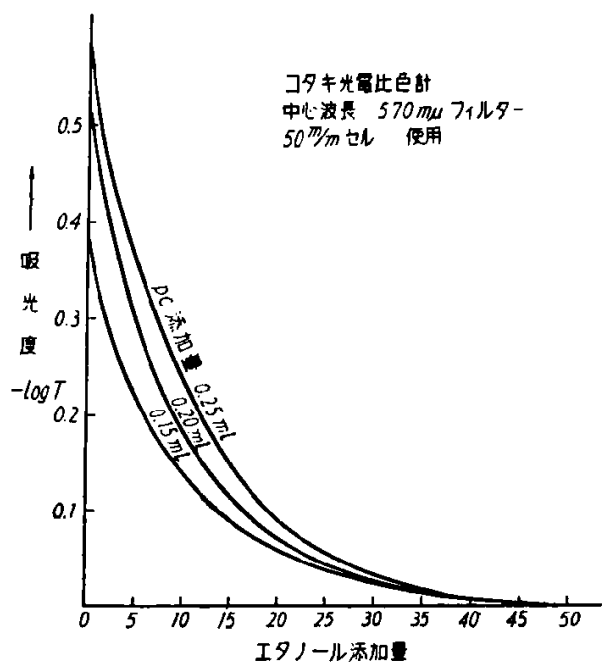

第2図エタノール添加によるPC の牫色消失曲線

液に PC 指示液 $0.15 \sim 0.25 \mathrm{~m} l$ を加え, $0.01 \mathrm{M}$ EDTA 標準 溶液で滴定し当量点上り $0.1 \mathrm{~m} l$ 過剩に加え，乙の残色溶液に エタノールを $5 \mathrm{ml}$ ずつ加えて，吸光度を测定した。結果は第 2 図のでとく滴定終了後の夜量に対して,エタノールを $15 \mathrm{ml}$ 加えたとてろより急激に色相か消失しているので，エタノール は $20 \mathrm{ml}$ 加元れば十分である。

また $50 \mathrm{ml}$ 中 $13.69 \sim 1.37 \mathrm{mg}$ のパリウムイオン濃度の各 㙁化バリウム浚液をそれぞれ $50 \mathrm{~m} l$ とり, $\mathrm{PC}$ 指示液 $0.15 \mathrm{~m} l$ および $0.25 \mathrm{ml}$ 加元て，0.01 M EDTA 標準浴液で滴定し，釉 点にわける吸光度を测定し, 第 1 表に示した。終点にわける吸

\begin{tabular}{|c|c|}
\hline 測定条件 & $\begin{array}{l}\text { コタキ光電比色計（電源電压 } \\
\text { 中心波長 } 570 \mathrm{~m} \mu \\
2 \mathrm{~cm} \text { セル }\end{array}$ \\
\hline
\end{tabular}

\begin{tabular}{|c|c|c|c|}
\hline \multirow{2}{*}{$\begin{array}{l}50 \mathrm{ml} \text { 中のバリゥ } \\
\text { ムイオン mg }\end{array}$} & \multirow{2}{*}{ 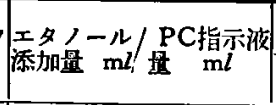 } & 終点の吸光度 & $-\log T$ \\
\hline & & 1 回 & 2 回 \\
\hline 13.69 & $20 / 0.15$ & 0.032 & 0.033 \\
\hline 9.59 & $20 / 0.15$ & 0.025 & 0.024 \\
\hline 6.85 & $20 / 0.15$ & 0.019 & 0.020 \\
\hline 5.48 & $20 / 0.15$ & 0.017 & 0.016 \\
\hline 1.37 & $20 / 0.15$ & 0.015 & 0.016 \\
\hline 13.69 & $20 / 0.25$ & 0.049 & 0.048 \\
\hline 13.69 & $20 / 0.25$ & 0.049 & 0.047 \\
\hline 13.69 & $20 / 0.25$ & 0.051 & 0.052 \\
\hline
\end{tabular}

光度湖定絬果より干涉する共存イオンがなければ，0.15〜0.25 $\mathrm{ml}$ の PC 指示液添加に上。て, 釉点の色相変化を明確汇把握 することができろので，本実釦にわいては $0.20 \mathrm{ml}$ とするて とにした。

\section{2 滴定方法の答点におよばす影量}

硫酸イオンを定量する場台，当量よりやや過剩のBa-EDTA を加元て，遊離する EDTA を塩化バリウム標㔼容液で滴定し， 無色から紫赤色人の変色点を求める方法と, 硫酸イオン亿当量 よりやや過剩の塩化バリウム標準溶液を加えて，残存するパリ ウムイオンを EDTA 標準溶液で滴定し，紫赤色より無色人 の変色点を求めろ方法の 2 法があり，両者のうちいずれか精度 よく测定できるか榆討した。

EDTA または塩化バリウムの標隼溶液の一定量をとり $50 \mathrm{ml}$ 
第2 表 EDTA 標準溶液の堨化ペリウム 標準浴液による滴定

\begin{tabular}{|c|c|c|c|}
\hline \multirow{2}{*}{$\begin{array}{l}\text { 当量バリムに換 } \\
\text { 蕒した埰取量 mg (1) }\end{array}$} & \multicolumn{2}{|c|}{ 塩化バリウム溶液の滴定量 } & \multirow{2}{*}{ (3) $\stackrel{\text { 差 }}{-}(1)$} \\
\hline & 力洒補正值 (2) & $\begin{array}{c}\text { パリ } \\
\mathrm{mg}(3)\end{array}$ & \\
\hline 12.73 & 9.27 & 12.73 & 0.00 \\
\hline 12.73 & 9.26 & 12.72 & -0.01 \\
\hline 12.73 & 9.27 & 12.73 & 0.00 \\
\hline 12.73 & 9.25 & 12.71 & -0.02 \\
\hline 12.73 & 9.25 & 12.71 & -0.02 \\
\hline 9.90 & 7.21 & 9.90 & 0.00 \\
\hline 9.90 & 7.20 & 9.89 & -0.01 \\
\hline 9.90 & 7.20 & 9.89 & -0.01 \\
\hline 9.90 & 7.20 & 9.89 & -0.01 \\
\hline 7.07 & 5.15 & 7.07 & 0.00 \\
\hline 7.07 & 5.14 & 7.06 & -0.01 \\
\hline 7.07 & 5.14 & 7.06 & -0.01 \\
\hline 7.07 & 5.14 & 7.06 & -0.01 \\
\hline 4.24 & 3.09 & 4.24 & 0.00 \\
\hline 4.24 & 3.10 & 4.26 & +0.02 \\
\hline 4.24 & 3.08 & 4.23 & -0.01 \\
\hline 4.24 & 3.08 & 4.23 & -0.01 \\
\hline 1.41 & 1.03 & 1.41 & 0.00 \\
\hline 1.41 & 1.02 & 1.40 & -0.01 \\
\hline
\end{tabular}

第3 表 塩化バリウム標染溶液の EDTA 標濩溶液による滴定

\begin{tabular}{|c|c|c|c|}
\hline \multirow{2}{*}{ 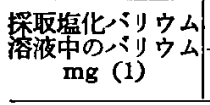 } & \multicolumn{2}{|c|}{ EDTA 溶液の 滴定量 } & \multirow{2}{*}{ (3) $\stackrel{\text { 差 }}{-}$ (1) } \\
\hline & 力洒補正值 (2) & \begin{tabular}{|l|} 
賞量 $\mathrm{mg}$ (3) \\
\end{tabular} & \\
\hline 13.69 & 9.97 & 13.69 & 0.00 \\
\hline 13.69 & 9.98 & 13.70 & +0.01 \\
\hline 13.69 & 9.99 & 13.72 & +0.03 \\
\hline 12.69 & 9.96 & 13.68 & -0.01 \\
\hline 13.69 & 9.97 & 13.69 & 0.00 \\
\hline 9.59 & 6.96 & 9.56 & -0.03 \\
\hline 9.59 & 6.98 & 9.59 & 0.00 \\
\hline 6.85 & 4.98 & 6.84 & -0.01 \\
\hline 6.85 & 5.00 & 6.87 & +0.02 \\
\hline 6.85 & 4.97 & 6.83 & -0.02 \\
\hline 5.48 & 3.97 & 5.45 & -0.03 \\
\hline 5.48 & 3.99 & 5.48 & 0.00 \\
\hline 1.37 & 0.99 & 1.36 & -0.01 \\
\hline 1.37 & 1.00 & 1.37 & 0.00 \\
\hline
\end{tabular}

とし， $\mathrm{pH} 11$ 亿調整してェタノール $20 \mathrm{ml}$ を加え，㙁化バリ ウムまたは EDTA の標準溶液で滴定し，絬果は第 2 表わよび 第3表に示した。

とれらの結果から終点は, EDTA 標準溶液を塩化バリウム 標準溶液で滴定する方法のはうが，やや精度よく测定できるこ とがわかる。なお実漈讁用するに当って第3表の方法は，2 種類の標準溶液を反復使用し操作か襀雑で誤差を大きくしやす い。したがって本研究には第 2 表の方法を採用するとととし た。

\section{3 共存イオンの影国}

アルカリ性溶液で滴定定量する本法では，混入するアルカリ 金属イオンおよび重金属イオンが共に妨害するととは明暸であ ろが，種々の添加戍を含まない純鉱油について㭇討する本研究 にわいては，多量には共存しないと考えられる。それゆ元原湤 または石汕精製過程より混入すると推察される璉々のイオンの

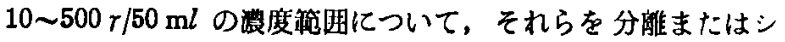

第4 表 鉄イオン $\left(\mathrm{Fe}^{\mathrm{8}+}\right)$ の影帮

\begin{tabular}{|c|c|c|c|c|c|}
\hline \multirow{2}{*}{ 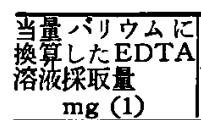 } & \multicolumn{2}{|c|}{$\begin{array}{l}\text { 鉄溶莄 (11.4 } \\
\mathrm{m} l \text { ) 添扣量 (2) }\end{array}$} & \multicolumn{2}{|c|}{$\begin{array}{l}\text { 腹化パリウム溶液 } \\
\text { 㴼定量 }\end{array}$} & \multirow{2}{*}{ (4) $\frac{\text { 差 }}{-(1)}$} \\
\hline & $\mathrm{m} l$ & $\begin{array}{c}\text { 鉄含有量 } \\
r\end{array}$ & \begin{tabular}{|c|} 
力価補正值 \\
$\mathrm{ml}(\mathrm{l})(3)$
\end{tabular} & $\begin{array}{l}\text { ベリウム } \\
\text { mg (4) }\end{array}$ & \\
\hline 12.73 & 1 & 11.4 & 9.27 & 12.73 & 0.00 \\
\hline 12.73 & 2 & 22.9 & 9.27 & 12.73 & 0.00 \\
\hline 7.07 & 1 & 11.4 & 5.15 & 7.07 & 0.00 \\
\hline 7.07 & 2 & 22.9 & 5.14 & 7.06 & -0.01 \\
\hline 7.07 & 5 & 57.2 & 5.05 & 6.94 & -0.13 \\
\hline 7.07 & 10 & 114.4 & 4.93 & 6.77 & -0.30 \\
\hline 7.07 & 25 & 286 & 4.60 & 6.32 & -0.75 \\
\hline 7.07 & 50 & 572 & 4.20 & 5.52 & -1.55 \\
\hline
\end{tabular}

第5 表 リン酸イオン (PO\&) の影響

\begin{tabular}{|c|c|c|c|c|c|}
\hline 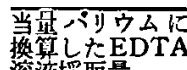 & $\begin{array}{l}\text { Ty } \\
\mathrm{m} l)\end{array}$ & $\begin{array}{l}\text { 夜 }(8.8 \gamma) \\
\text { 加量 (2) }\end{array}$ & \begin{tabular}{|l|} 
猵化涌定 \\
量
\end{tabular} & ウム溶液 & \\
\hline $\begin{array}{c}\text { 溶液採取量 } \\
\text { mg }(1) \\
\end{array}$ & $\mathrm{m} l$ & リン含有豆 & 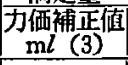 & $\begin{array}{l}\text { バリヴ } \\
\mathrm{mg}(4)\end{array}$ & (4)-(1) \\
\hline 12.42 & 0 & 0 & 9.05 & 12.43 & +0.01 \\
\hline 12.42 & 1 & 8.8 & 9.04 & 12.42 & 0.00 \\
\hline 12.42 & 2 & 17.5 & 9.04 & 12.42 & 0.00 \\
\hline 12.42 & 5 & 43.8 & 9.05 & 12.43 & +0.01 \\
\hline 12.42 & 10 & 87.5 & 9.04 & 12,42 & 0.00 \\
\hline 12.42 & 25 & 219 & 9.05 & 12.43 & +0.01 \\
\hline 12.42 & 50 & 438 & 9.04 & 12.42 & 0.00 \\
\hline
\end{tabular}

第 6 表 銅イオン $\left(\mathrm{Cu}^{8+}\right)$ の影櫭

\begin{tabular}{|c|c|c|c|c|c|}
\hline \multirow{2}{*}{ 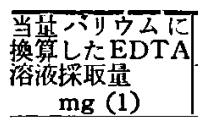 } & \multicolumn{2}{|c|}{ 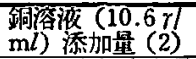 } & \multicolumn{2}{|c|}{ 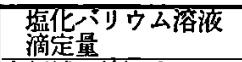 } & \multirow{2}{*}{ (4) $\stackrel{\text { 差 }}{-}(1)$} \\
\hline & $\mathrm{m} l$ & $\frac{\text { 銅含有望 }}{\gamma}$ & $\begin{array}{c}\text { 力価補正做 } \\
\mathrm{ml}(3)\end{array}$ & $\begin{array}{l}\text { ベリウム } \\
\mathrm{mg}(4)\end{array}$ & \\
\hline 12.42 & 1 & 10.6 & 9.05 & 12.43 & +0.01 \\
\hline 12.42 & 2 & 21.2 & 9.05 & 12.43 & +0.01 \\
\hline 12.42 & 5 & 53.0 & 9.04 & 12.42 & 0.00 \\
\hline 12.42 & 10 & 106.0 & 9.00 & 12.36 & -0.06 \\
\hline 12.42 & 25 & 265 & 8.69 & 11.95 & -0.47 \\
\hline 12.42 & 50 & 530 & 8.25 & 11.33 & -1.09 \\
\hline
\end{tabular}

第7表 两鉛イオン $\left(\mathrm{Zn}^{2+}\right)$ の影㸷

\begin{tabular}{|c|c|c|c|c|c|}
\hline \multirow{2}{*}{ 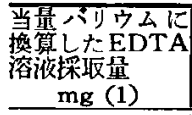 } & \multicolumn{2}{|c|}{ 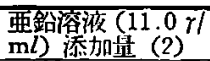 } & \multicolumn{2}{|c|}{ 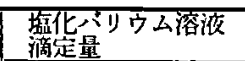 } & \multirow{2}{*}{ (4) $\stackrel{\text { 差 }}{-}(1)$} \\
\hline & $\mathrm{m} l$ & 业鉛含有最 & 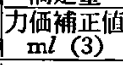 & 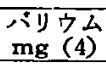 & \\
\hline 12.42 & 1 & 11.0 & 9.04 & 12.42 & 0.00 \\
\hline 12.42 & 2 & 22.0 & 9.04 & 12.42 & 0.00 \\
\hline 12.42 & 5 & 54.9 & 9.03 & 12.40 & -0.02 \\
\hline 12.42 & 10 & 109.8 & 8.93 & 12.27 & -0.05 \\
\hline 12.42 & 25 & 274 & 8.70 & 11.94 & -0.48 \\
\hline 12.42 & 50 & 549 & 8.23 & 11.30 & -1.12 \\
\hline
\end{tabular}

第8表 カルシウム イオン $\left(\mathrm{Ca}^{2+}\right)$ の影䣽

\begin{tabular}{|c|c|c|c|c|c|}
\hline \multicolumn{5}{|c|}{ 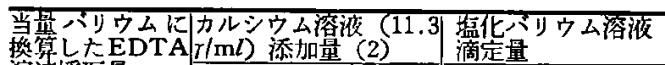 } & \multirow{2}{*}{ (4) $\stackrel{\text { 差 }}{-(1)}$} \\
\hline $\begin{array}{r}\text { 溶液採取量 } \\
\text { mg (1) }\end{array}$ & $\mathrm{m} l$ & 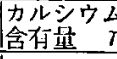 & $\begin{array}{c}\text { 力価補正似 } \\
\mathrm{m} l(3)\end{array}$ & $\begin{array}{l}\text { Piリウ } \\
\text { mg (4) }\end{array}$ & \\
\hline 12.42 & 1 & 11.3 & 9.04 & 12.42 & 0.00 \\
\hline 12.42 & 2 & 22.6 & 9.02 & 12.38 & -0.04 \\
\hline 12.42 & 5 & 56.6 & 8.99 & 12.34 & -0.08 \\
\hline 12.42 & 10 & 113.3 & 8.80 & 12.09 & -0.33 \\
\hline 12.42 & 25 & 283 & 8.36 & 11.49 & -0.93 \\
\hline 12.42 & 50 & 567 & - & - & - \\
\hline
\end{tabular}

ヤへイすることなく滴定した場合の，测定值に及ばす影掣を調 查した。

実殹絬果は第 4〜日表のとおりであり,リン酸イオン以外の 程々の共存イオンの影豐を受けるととがわかる。とれらのうち 
覀鉛, 鉄, 銅イオンは, シアン化カリウムでシャへイして干涉 を防ぐことができるが，カルシウム，マグネシウムイオンは 多量に存在すれば分離しなければならない。しかし睡述のごと く武料中にはとのような共存イオンはでく微量程度しか含まれ ないと考元られ，分析操作中においても，てれらのイオンが混 入しないような方法を採用しているので,てれらの共存イオン の影響は無視できる。

\section{4 燃焼操作の検討}

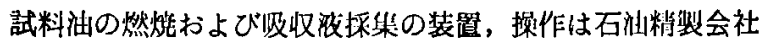
で一般に使朋されているボンブ法 (JIS K-2263, ASTM D129）の規定に従い，ボンブ内吸収液の種類とボンブ洗浄水量 について検討した。

\section{1) 洗净水量の検討}

JIS K-2263 亿従えば洗净水量は通常 $300 \mathrm{ml}$ 程度になるが， 操作を迅速に行なうためとの是をできるだけ娍少させる実験を した。

すなわち炭酸ナトリウム溶液 $5 \mathrm{~m} l$ を吸収液とし，ボンブ中 でイオウ分既知式料（イオウ分： $1.02 \mathrm{wt} \%$ ) を然焼し，ボンブ の任力を抜いてフタをはずし，ボンブ内各部を $50 \sim 500 \mathrm{~m} l$ の おのおのの純水量で洗い，洗液を $600 \mathrm{~m} l$ ビーカーに集めろ。 以下 JIS K-2263に従って亜硫酸の酸化, 硫酸バリウム沈貱の 生成，口過，乾燥，ヒョウ量を行なって，イオウ分を定量した。

絬果は第 9 表に示すごとく，試験法規定の洗净水量より少な くても精度よく测定できるととがかかった。

第 9 表 洗浄水量に関する実跉

\begin{tabular}{|c|c|c|c|c|}
\hline $\begin{array}{c}\text { 試料啋取量 } \\
\mathrm{mg}\end{array}$ & $\begin{array}{c}\text { 洗浄水量 } \\
\mathrm{m} l\end{array}$ & $\begin{array}{c}\text { 沈殿 量 } \\
\text { mg }\end{array}$ & $\begin{array}{c}\text { イオウ分 } \\
\text { wt\% }\end{array}$ & 既知量との差 \\
\hline 786.4 & 50 & 59.5 & 1.02 & 0.00 \\
\hline 796.5 & 100 & 59.9 & 1.01 & -0.01 \\
\hline 775.2 & 150 & 59.2 & 1.02 & 0.00 \\
\hline 790.5 & 200 & 59.7 & 1.01 & -0.01 \\
\hline 779.2 & 250 & 59.4 & 1.02 & 0.00 \\
\hline 772.7 & 300 & 59.2 & 1.03 & +0.01 \\
\hline 787.6 & 400 & 59.7 & 1.02 & 0.00 \\
\hline 791.7 & 500 & 60.2 & 1.02 & 0.00 \\
\hline ブランク & 300 & 1.3 & - & - \\
\hline
\end{tabular}

2) 吸收液の検討

キレート分析法によって吸収液中の硫酸イオンを定量する場 合，炭酸ナトリウム溶液を吸収液として使用すると，アルカリ 性で行なうため炭酸バリウムを生成して，誤差を生ずるのと， 多量のナトリウムイオンが硫酸バリウムの沈没生成を妨害す る欠点がある ${ }^{10}$ ので，吸収液として純水の使用可否を梌討した。 吸収液のみ純水 $5 \sim 10 \mathrm{~m} l$ として, 前記実殹と同一詿料, 问 一操作によって，武料の然狫，器具の洗净，イオン含有溶液の 採集, 悪硫酸の酸化を行なった。

硫酸バリウ

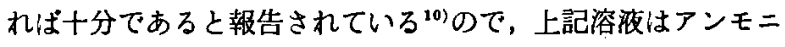
ア水 $(1: 1)$ および塩酸 $(1: 4)$ で $\mathrm{pH}$ を 3に調整した のち，前記実験と同一方法によって，イオウ分を定量した。

結果は第 10 表に示すごとく，イオウ酸化物の吸収には 5〜 $10 \mathrm{~m} l$ の純水でよく，沈䟝熟成時間も短時間の加温故置でよい 絬果が得られた。

\section{5 測定操作の検討}

第 10 表 吸收洨および沈殿熟成時間に関する実験

\begin{tabular}{|c|c|c|c|c|}
\hline $\begin{array}{c}\text { 訊料採取量 } \\
\text { mg }\end{array}$ & $\begin{array}{c}\text { 洗浄水量 } \\
\text { m } l\end{array}$ & $\begin{array}{c}\text { 沈 殿 } \\
\text { mg }\end{array}$ & $\begin{array}{l}\text { 1オウ分 } \\
\text { wt\% }\end{array}$ & 既知量との差 \\
\hline 798.2 & 50 & 60.7 & 1.02 & 0.00 \\
\hline 785.9 & 100 & 59.4 & 1.01 & -0.01 \\
\hline 782.9 & 150 & 60.9 & 1.04 & +0.02 \\
\hline 791.6 & 200 & 61.2 & 1.03 & +0.01 \\
\hline 797.6 & 250 & 60.5 & 1.02 & 0.00 \\
\hline 793.7 & 300 & 60.9 & 1.03 & +0.01 \\
\hline 791.5 & 400 & 60.0 & 1.02 & 0.00 \\
\hline 800.0 & 500 & 60.2 & 1.01 & -0.01 \\
\hline ブランク & 300 & 1.4 & - & - \\
\hline
\end{tabular}

Ba-EDTA 浴波の添加量, 滴定時の地敳の処理, 酸化郕の 䅜類および添加量について梌討した。

3.1）の武料 0.7 0.8 g をはかり取り，純水 $10 \mathrm{~m} l$ を用い て4.40実醉と同一方法で試料を然焼する。ボンブ内および式 料ザラは全洗净液量が $100 \sim 150 \mathrm{~m} l$ になるように純水で洗净 し,洗液は $200 \mathrm{~m} l$ ビーカーに集め, 㙁酸 $(1: 4)$ を加えて pH 1 〜2 の酸性とし，酸化郕を加えて熱板上で $30 \mathrm{~min}$ 沸鰧（酸化 郕を完全に追い出す) する。つざにアンモニア水 (1：1）およ び醏酸 (1:4)で pH 2.5 3.5 に調整して，Ba-EDTA 浴湤を 加え，棐かにかきまぜながら 1 2 hr 故置する。生成した沈既 は東洋口紙 No. 7 で口別し， 口夜は他の $200 \mathrm{~m} l$ ビーカーに 集め, 裣アンモ二ア水を加えて $\mathrm{pH}$ 11〜11.4 とし、ただちに エタノール $20 \mathrm{~m} l$, フタレインコンプレキンン指示液 $0.20 \mathrm{~m} l$ を加えて，0.01M 塩化バリウム標準溶液で滴定しだ。

絬果は第 11 表に示すごとく, Ba-EDTA 溶液の添加量は武

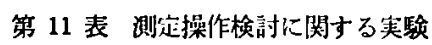

\begin{tabular}{|c|c|c|c|c|c|c|}
\hline \multirow{2}{*}{$\begin{array}{c}\text { 試料採取量 } \\
\text { mg }\end{array}$} & \multicolumn{2}{|c|}{ 酸 化 绪 } & \multicolumn{3}{|c|}{ Ba-EDTA 溶液塩华沙吊 } & \multirow{2}{*}{$\begin{array}{c}\text { イオウ分 } \\
\text { wt\% }\end{array}$} \\
\hline & 種 類 & $\begin{array}{c}\text { 添加量 } \\
\mathrm{m} l \\
\end{array}$ & モル等度 & $\begin{array}{c}\text { 添加量 } \\
\mathrm{m} l\end{array}$ & 皇唂似调㱜 & \\
\hline ブランク & $\mathrm{Br}_{\mathrm{r}}$ & 5 & 0.01 & 25 & 0.31 & - \\
\hline 759.6 & $\mathrm{Br}$ & 5 & 0.01 & 25 & 11.38 & 0.496 \\
\hline 755.6 & $\mathrm{Br}$ & 5 & 0.01 & 25 & 11.36 & 0.497 \\
\hline ブランク & $\mathrm{Br}$ & 5 & 0.01 & 50 & 0.59 & - \\
\hline 780.0 & $\mathrm{Br}$ & 5 & 0.01 & 50 & 11.56 & 0.500 \\
\hline 776.1 & $\mathrm{Br}$ & 5 & 0.01 & 50 & 11.54 & 0.501 \\
\hline 783.4 & $\mathrm{Br}$ & 10 & 0.01 & 25 & 11.78 & 0.498 \\
\hline 788.8 & $\mathrm{Br}_{\mathrm{r}}$ & 10 & 0.01 & 25 & 12.08 & 0.504 \\
\hline 781.0 & $\mathrm{Br}$ & 10 & 0.01 & 50 & 11.63 & 0.502 \\
\hline 798.7 & $\mathrm{Br}$ & 10 & 0.01 & 50 & 11.62 & 0.492 \\
\hline ブランク & $\mathrm{H}_{2} \mathrm{O}_{2}$ & 1 & 0.02 & 10 & 0.08 & - \\
\hline 766.9 & $\mathrm{H}_{2} \mathrm{O}_{2}$ & 1 & 0.02 & -10 & 11.89 & 0.500 \\
\hline 788.0 & $\mathrm{H}_{2} \mathrm{O}_{2}$ & 1 & 0.02 & 10 & 12.27 & 0.503 \\
\hline
\end{tabular}

料浴液中の硫酸イオンと反応する当量より少過剩に加えれば十 分であり，硫酸バリウムの地没は口過分䇆したので，滴定終点 を明椎に测定できた。酸化棛としては飽和臭素水と過酸化水素 水のいずれでもよく, 前者は $5 \sim 10 \mathrm{ml}$, 後者は $1 \mathrm{ml}$ 添加すれ ばよいことがわかった。

\section{6 石油留分中のイオウ分の定量}

イオウ分合成試料および各種石油留分試料について, キレー ト法と JIS K-2263 法の両者でイオウ分を分析し, 比較検討し た結果，キレート法は JIS K-2263 法に匹敵する精度および正 碓さで適用できることが判明した。

1）イオウ分合成武料中のイオウ分の定些 
第 13 表 石油留分試料油中の全イオウ分分析結果

\begin{tabular}{|c|c|c|c|c|c|c|c|}
\hline \multirow{3}{*}{\multicolumn{2}{|c|}{ 陚料油名 }} & \multicolumn{6}{|c|}{ 全イオウ分分析值 (wt\%) } \\
\hline & & \multicolumn{3}{|c|}{ キレート法 } & \multicolumn{3}{|c|}{ JIS K-2263 法 } \\
\hline & & 1 回 & 2 回 & 差 & 1 回 & 2 回 & 3 回 \\
\hline 油 & A & 1.74 & 1.71 & 0.03 & 1.66 & 1.72 & 1.73 \\
\hline 油 & B & 1.97 & 2.04 & 0.07 & 2.05 & 2.06 & 2.10 \\
\hline 油 & $\mathrm{C}$ & 1.09 & 1.10 & 0.01 & 1.10 & 1.06 & 1.15 \\
\hline 油 & D & 2.93 & 2.92 & 0.01 & 3.02 & 2.93 & 3.01 \\
\hline 油 & E & 1.38 & 1.34 & 0.04 & 1.35 & 1.31 & 1.39 \\
\hline 軽 油留 5 & & 1.11 & 1.08 & 0.03 & 1.12 & 1.06 & 1.14 \\
\hline 軽質潤滑油留 & & 2.01 & 2.06 & 0.05 & 2.09 & 2.05 & 2.14 \\
\hline 中質閵猾油留分 & & 2.24 & 2.26 & 0.02 & 2.39 & 2.30 & 2.35 \\
\hline 中質潤滑油留分 I & & 2.42 & 2.44 & 0.02 & 2.42 & 2.41 & 2.47 \\
\hline 重貸潤愲油留分 & & 2.96 & 2.97 & 0.01 & 2.91 & 2.92 & 2.93 \\
\hline 重質潤滑油留分 & & 2.63 & 2.69 & 0.06 & 2.64 & 2.63 & 2.69 \\
\hline
\end{tabular}

3.1）のイオウ分合成試料化つて検討し，結果は第 12 表に 示した。

第 12 表を用い，雨法の差の桧定を行なったとてろ， 差の平均値 $\bar{d}=(-3 / 10) \times 1000^{-1}=-0.0003$ $d$ の偏差 2 乘和 $S_{d}=\Sigma d^{2}-\frac{(\Sigma d)^{2}}{n}$

$$
\begin{aligned}
& =\frac{1}{1000}\left\{\Sigma(1000 d)^{2}-\frac{(\Sigma 1000 d)^{2}}{n}\right\} \\
& =\frac{1}{1000}\left(285-\frac{-3^{2}}{10}\right)=\frac{284.1}{1000^{2}}
\end{aligned}
$$

$d$ の不编分散 $\quad V_{d}=\frac{S_{d}}{n-1}=\frac{284.1}{9 \times 1000^{2}}$

$$
t_{0}=\frac{\bar{d}}{\sqrt{\overline{V_{d} / n}}}=\frac{-0.0003}{\sqrt{\frac{284.1}{9 \times 1000^{2} \times 10}}} \div-0.17
$$

したがって $t$ 分布表より。とれら両法の試験值の間仙差が あるとはい兊ず,かつキレート法試験值の反復性も JIS K-2263 規定の精度内に十分入っていることがわかる。

2）石油留分試料中のイオウ分の定量

3.1) の原油, 軽油, 減滑油留分の各種陚料について椧討し, 結果は第 13 表に示した。

これらの分析値においても, キレート法の精度ははとんど JIS K-2263 に匹敵しているととかかかる。

\section{5. 試験法の確立}

以上の実験より次のでとき全イオウ分定量法を確立しだ。

JIS K-2263 法に従いボンブ内に試料ザラを取りつけ（ただ し吸収夜は純水 $10 \mathrm{~m} l$ とする)，酸素を压入し試料を燃狫する。 つぎにイオウ含有溶液の採集, 同溶液の酸化, $\mathrm{pH}$ の調整は 4.5 の操作従って行ない，0.02 M Ba-EDTA 溶液 $10 \mathrm{~m} l$ t

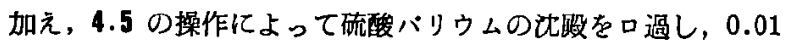
$\mathrm{M}$ 塩化バリウム標準溶液による滴定を行なう。無色から紫赤 色への変色点までに要した同溶夜の消费量を記録する。

試蒋または希橎剤の新しいるのを用いるごとに試料なしで上

\begin{tabular}{|c|c|c|c|c|}
\hline \multirow{2}{*}{ 試 料 } & \multicolumn{2}{|c|}{ 全イオウ分分析值（wt\%） } & \multirow{2}{*}{$(d) \stackrel{\text { 差 }}{1}$} & \multirow{2}{*}{$(d \times 1,000)^{2}$} \\
\hline & キレート法 & $\mid \mathrm{JIS} \mathrm{K}-2263$ 法 & & \\
\hline \multirow[t]{2}{*}{ A } & 0.501 & 0.492 & +9 & 81 \\
\hline & 0.497 & 0.488 & +9 & 81 \\
\hline \multirow[t]{2}{*}{ B } & 0.171 & 0.179 & -8 & 64 \\
\hline & 0.169 & 0.176 & -7 & 49 \\
\hline \multirow[t]{2}{*}{$\mathbf{D}$} & 0.050 & 0.050 & 0 & $\mathbf{0}$ \\
\hline & 0.049 & 0.050 & -1 & 1 \\
\hline \multirow[t]{2}{*}{$\mathrm{D}$} & 0.035 & 0.036 & -1 & 1 \\
\hline & 0.036 & 0.038 & -2 & 4 \\
\hline \multirow[t]{2}{*}{$\mathbf{E}$} & 0.006 & 0.008 & -2 & 4 \\
\hline & 0.007 & 0.007 & 0 & 0 \\
\hline 計 & & & -3 & 285 \\
\hline
\end{tabular}
記同一操作でブランク テストを行ない，次式によって全イオ
第 12 表 合成試料油中の全イオウ分分析結果

ウ分を算出する。

全イオウ分 $(\mathrm{wt} g \%)=\frac{(P-B) \times F \times 0.032}{W}$

$P$ : 武料の滴定に要した $0.01 \mathrm{M}$ 塩化バリウム標準溶液の 量 $(\mathrm{m} l)$

$B:$ ブランク テストに要した $0.01 \mathrm{M}$ 塭化パリウム標準 浴液の量 $(\mathrm{m} l)$

$F: 0.01 \mathrm{M}$ 㙁化バリウム標準㴦液の力佂

$W:$ 試料の重量（g)

6. 結 語

JIS K-2263 で得られた硫酸イオンに Ba-EDTA 錯塩を加 え，㙁化バリウムで逆滴定して，重筫石油留分中の全イオウ分 を定量する方法について述へた。実蛤の結果 JIS K-2263 に匹 敵する精度と正確さで分析できるととがわかった。従来は簡便 法として, 石英管然焼法 (JIS K-2273, ASTM D-1551) によ り迅速に行なっており，塩素イオンが共存すればそれを定量し て補正を行なわなければならず，またリン酸イオンがあ机ば干 渉して分析できないなどの欠点があったが，本法によれぱてれ らの問題か澥消され，石油精製工場の日常管理の試験法として 適当と思われる。

\section{引用 女 城}

1）日本工業規格，K-2263 (1959).

2) Am. Soc. Testing Materials, Philadelphia, Pa., "Standards on Petroleum Products and Lubricants", 81 (1958).

3）日本工業規格，K-2273 (1959).

4) Am. Soc. Testing Materials, Philadelphia, Pa., "Standards on Petroleum Products and Lubricants", 894 (1958).

5) J.A. Hidy and R.D. Mair, Anal. Chem., 27, 802 (1955).

6) 武藤, 比色分析法, 共立社, 144 (1955).

7) 营野, 分析化学, 8, 180 (1959).

8) O.N. Hinsvark and F.J. O'Hara, Anal. Chem., 29, 1318 (1957).

9) T.J. Manns, M.U. Reschovsky and A.J. Certa, ibid, 24, 908 (1952).

10）入谷, 田中, 分析化学, 7,42 (1958).

11）入谷, 田中, 同上, 8, 30 (1959). 